\title{
School readiness assessment: Study of early childhood educator experience
}

\begin{abstract}
Lumaurridlo, Department of Educational Research and Evaluation, Graduate School, Yogyakarta State University \& Institut Agama Islam Imam Ghozali, lumaurridlo.2018@student.uny.ac.id, ORCID: 0000-00028695-466
\end{abstract}

Heri Retnawati, Department of Educational Research and Evaluation, Graduate School, Yogyakarta State University, heri_retnawati@uny.ac.id, ORCID: 0000-0002-1792-5873

Hanif Cahyo Adi Kistoro Department of Islamic Education, Faculty of Islamic Religion, Ahmad Dahlan University, hanif.kistoro@pai.uad.ac.id, ORCID: 0000-0003-1330-2991

Himawan Putranta, Department of Education Science, Concentration of Physics Education, Graduate School, Yogyakarta State University, himawanputranta.2020@student.uny.ac.id, ORCID: 0000-0003-2646-8237

\begin{abstract}
The physical and psychological readiness of children will affect the transition phase of children entering more formal education. Increasing children's' school readiness is one the most important aims of quality early childhood education. This research aims to explore the experiences of early childhood educators in assessing the level of readiness of children entering primary education. This research is qualitative research using a phenomenological approach. Data was collected through focus group discussions (FGDs) involving 20 early childhood educators who covered kindergarten, RA, and PAUD in Cilacap, Central Java, Indonesia. The data analysis technique was carried out by applying the Miles and Huberman model. The results showed the concept of school readiness has been widely recognized by early childhood educators and colored the process of early childhood learning. Educators' perceptions of the dimensions of school readiness are based on the achievements of children's development, which include moral and religious values, physical-motor, cognitive, language, social-emotional, and art. The assessment of the child's developmental achievements is carried out formative with most using performance assessments. The plural assessment rubric is used as an observation instrument for the child's performance.
\end{abstract}

Keywords: School readiness, Early childhood, Assessment

Received: 26.05 .2020

Accepted: 04.08.2020

Published: 01.12.2020

\section{INTRODUCTION}

The age of children, entering primary school in many countries has different minimum limits. Countries in Europe mostly limit the minimum entrance to primary school is at the age of six years, although some countries such as the United Kingdom, the Netherlands, and Malta start at a younger age of 5 years and Northern Ireland at 4 years, while Bulgaria, Finland, and some countries others start at the age of 7 years (DfE, 2016). The United States requires children who have entered 5 years to enter primary education including 1-year pre-school (NCES, 2016). While Indonesia based on Minister of Education and Culture Regulation number 14 of 2018 limits the age of entering primary school is a minimum of six years except 5.5 years of age for children with special intelligence or talent and psychic readiness. This is in line with the majority of countries in Asia where the age of entering primary school at the age of 6 years (Sha \& Li, 2019).

Besides age, other factors in the transition phase of children entering primary school require special attention. The involvement of parents and schools becomes important in preparing the phase of children entering primary school. UNICEF (2012) conceptualizes the readiness of children, schools, families, and the community to help children enter primary education. The readiness concept is used to design and organize early years education through performance standards and measures, graduation rates and thresholds not met (Wood, 2019). Conditioning classroom structures and organizations and implementing game-based learning strategies contributes to adjustment in the early phases of school (Booth et al., 2019; Putranta \& Wilujeng, 2019). 
One strategy for preparing children to take part in formal education is early childhood education or pre-school education. The importance of pre-school education is to facilitate children to obtain maturity and independence with the help of adequate systems and infrastructure (Amerijckx \& Humblet, 2015). Using the term Broström (2005) cultural shock often occurs in the transition phase of entering schools and different learning systems, where the challenges they have to face every day tend to hinder - rather than stimulate - their learning. The problems that often arise are not only changed in place and culture but rather a separation from old friends and entering new communities that children feel is a big problem in transition (Ackesjö, 2015).

The concept of school readiness, in general, has been widely understood the level of pedagogy and practice of pre-school teacher education and early childhood education (Amerijckx \& Humblet, 2015; Hamerslag et al., 2018; Hellblom-Thibblin et al., 2017; Van Laere \& Vandenbroeck, 2017). As a formal form to facilitate readiness to enter primary school, early childhood education including pre-school education is, of course, more dominant on needs compared to care. This was questioned by Bennett (2013) because it was deemed not to respect the potential of children and was counterproductive like schools that only facilitate early childhood academics (Moss, 2013). Implementation of the concept of school readiness in early childhood education also raises new problems, namely injustice to underprivileged families who do not have access to it or families who do not facilitate children in formal education at an early age (Brooks \& Murray, 2018; Wilder \& Lillvist, 2017). While research findings in poor areas in Dublin, Ireland (Booth et al., 2019) children describe schools needing to regulate their emotional, cognitive, and behavioral responses.

Another problem arises in the handling of gifted children who enter school earlier than normal children. In general, gifted children have excellence in academics, but as a whole individual, it must be followed by the development of other aspects, so that as a whole as a balanced person (Wahab, 2005). Regulation of the Minister of Education and Culture Number 14 of 2018 concerning the Admission of New Students to Kindergartens, Elementary Schools, Junior High Schools, Senior High Schools, Vocational High Schools, or Other Forms of the Equivalent explicitly states that primary schools are obliged to accept students who are 7 years old. Exceptions for a minimum age of 6 years can be granted at least five years and six months on July 1 of the current year for prospective students with special intelligence/special talents and psychological readiness. This rule is important to underline the requirements for chronological age children who have not met 7 years of age to enter elementary school with special intelligence or talent and psychological readiness. Wellisch's (2019) research produced findings that show early childhood educators' confusion over the intellectual, social, and emotional needs of gifted children that are not understood or fulfilled according to their parents.

The problem is development and maturity for each individual is different (Miller, 2011). It could be that there are students who are not yet 7 years old, but their growth and development and maturity are ready to enter school. On the other hand, it is possible that even though the age is 7 years old, it is not yet mature to enter primary school. However, research by Dockett and Perry (2002) recommends that chronological age should still be considered because it has a positive correlation with mental readiness and individual development. To guide this research, it is urgent to research related to school readiness. Research topics such as this have been widely studied, such as research conducted by Harris, et al. (2018), Holmes (2019), Miller-Bains et al. (2017), Setiawati et al. (2017), Sha \& Li (2019), Wolf, et al. (2017). Departing from the definition of school readiness put forward by Maxwell and Clifford (2004):

School readiness involves more than just children. School readiness is about children, families, early environments, schools, and communities. Children are not innately 'ready' or 'not ready' for school. Their skills and development are strongly influenced by their families and through interactions with other people and environments before coming to school. (p. 42).

School readiness is divided into two developing discourse constructs, namely readiness for learning and readiness for school (Kagan, 1990). Readiness to learn is conceptualized as a 
developmental progression that reflects a child's ability to learn defined curriculum content. This is influenced by motivation, physical development, intellectual abilities, emotional maturity, and health. Meanwhile, readiness for school is considered as a set of physical, intellectual, and/or social skills that are permanent or a prerequisite that is necessary for children to meet the requirements of the school environment (Scott-Little et al. 2006). Readiness in the context of school readiness is a multidimensional attribute, including children's skills, family and environmental factors, behavioral and cognitive aspects of child development, children's adaptation to the classroom, and the characteristics of the education system and community available to children and families (Arifin et al., 2020; Brown, 2015). Thus, school readiness can be conceptualized as a constellation of basic skills that children can use in combination to succeed in school.

Although morals and religion have not received much attention from many researchers, this dimension is an important dimension of religious readiness in several countries (Setiawati et al., 2017; Sha \& Li, 2019). Sha and Li (2019) found that religious values provide stimulation for early learning. Meanwhile, Setiawati et al. (2017) stated that religious activities, although not a very dominant factor, contribute to school readiness. Children's physical health is central to the development of skills necessary for successful transitions and first-time formal school experiences (Kull \& Coley, 2015). Nguyen et al. (2019) argue that the health dimensions that affect school readiness include self-care routines, healthy lifestyles, and personal safety. Meanwhile, from the motoric aspect, school readiness can be assessed from the development of gross and fine motor skills (Miller-Bains et al., 2017; Nguyen et al., 2019; Setiawati et al., 2017; Tortella et al., 2016), balance (Miller-Bains et al., 2017; Nguyen et al., 2019; Setiawati et al., 2017; Tortella et al., 2016), object control skills (Tortella et al., 2016).

Physical activities that involve locomotor (such as: running, jumping, and moving), object control skills (throwing, catching and kicking), and stability or balance skills (balancing, turning, and turning) support motor maturity so that children are more active (Tortella et al. al., 2016). Setiawati et al. (2017) added performance such as cutting and pasting, writing, holding stationery, drawing several curves, straight lines, and also boxes can be used to show fine motor skills. The results of research by Guarnera et al. (2017) show that basic linguistic, phonological, and mathematical skills are important scholastic learning as a basis for academic skills. Preschoolers can create representations in their minds that contain information about symbols and in the phases of pictographic development. They can also recognize familiar words from their overall form, but they cannot correctly match their corresponding phonemes and graphics. The issues from this research indicate that children who are ready for school can recognize familiar forms of objects and figures and to individualize the similarities between objects and abstract forms (Guarnera et al., 2017). Likewise, early mathematics learning is also a classic executive function challenge (Blair \& Raver, 2015). However, research by Quirk et al., (2017) shows that there is vulnerability if the demands for fluency in reading at pre-school age become the focal point of school readiness.

The dimension of early academic readiness is more focused on the ability to recognize letters and early counting (Blair \& Raver, 2015; Niklas, et al., 2018; Quirk et al., 2017; Setiawati et al., 2017). Meanwhile, Han and Neuharth-Pritchett (2017) argue that preschool children's letter recognition is a strong predictor of their literacy success in the future. Early mastery of math skills (particularly knowledge and numerical ordinality) was the strongest predictor of numeracy and literacy skills in school. Niklas (2018) findings show that children who demonstrate early academic competence and sustained attention are equipped to benefit more quickly from learning opportunities once they start school. The use of the mother tongue as the language of instruction has made a big contribution to improving vocabulary, including learning a second language (Limlingan et al., 2019). The language dimension in many findings becomes one dimension with literacy (Han \& Neuharth-Pritchett, 2017; Harris, et al., 2018; Holmes, 2019; Nguyen et al., 2019; Niklas, et al., 2018; ). The language dimension consists of aspects of language in conversation, concepts about writing, phonology, and knowledge of letters and words (Nguyen et al., 2019; Setiawati et al., 2017). Meanwhile, Zubaidah (2004) argues that children aged 5 to 6 
years have the correct sentence structure and grammar. The length of the sentence reaches 6 to 8 words per sentence, while the vocabulary has used 2500 words to 6000 words.

Other cognitive abilities that affect school readiness are understanding instruction and information, problem-solving (Setiawati et al., 2017; Nguyen et al., 2019), recognizing colors (Setiawati et al., 2017), while Nguyen et al. (2019) adds memory and knowledge, Curiosity and initiative as well as engagement and persistence. Wellisch (2019) found that many educators forget about the social and emotional dimensions by only recommending giftedness to intellectual and academic abilities. The consideration of emotional social maturity is an important aspect of school readiness (An \& Xie, 2018; Wellisch, 2019). The social-emotional dimension includes self-regulation (An \& Xie, 2018; Blair \& Raver, 2015; Raikes, et al., 2019; Setiawati et al., 2017) interpersonal interactions with peers (Booth et al., 2019; Blair \& Raver. , 2015; Setiawati et al., 2017), motivation, independence (Niklas, et al., 2018; Setiawati et al., 2017), cooperation and class adaptation (Setiawati et al., 2017). The dimension of art as a school readiness factor was only stated by Setiawati et al. (2017). This dimension consists of rhythm, sound and tone, drawing, and creativity. No other research results were found that included art in the dimensions of school readiness from the articles collected.

\section{The aim of the research}

This research aimed to obtain a description of the experiences of early childhood educators in assessing the readiness of children to attend learning in primary schools. The research questions used to elaborate on the objectives of this research are below.

1. Who does the school readiness assessor in early childhood education?

2. What is the experience of early childhood educators in assessing children's school readiness?

3. What factors are used to assess children's school readiness?

4. What has been done so far in supporting children's school readiness?

\section{METHODS}

\section{Design}

This research was designed to gain an understanding of the assessment and the dimensions used to assess early childhood school readiness. This research was conducted to explore the experiences of educators in assessing children's readiness to take formal learning in elementary schools and to obtain an overview of the dimensions used to assess children's readiness to participate in formal learning in primary schools and what has been done so far in supporting children's readiness. This research uses a phenomenological approach. This research was conducted from September to December 2019. In that range, researchers collected data through focus group discussions (FGD). Researchers also formed a WhatsApp group to follow up on the FGD and recover data that were not extracted in the FGD. FGD was held in October 2019.

\section{Participants}

The FGD participants were 20 early childhood educators in Cilacap, Central Java, Indonesia. All participants are female. Participant qualifications are early childhood educators who have facilitated PAUD learning for at least 5 years.

\section{Data analysis}

The FGD participants shared experiences related to the process of assessing the school readiness of carried out all this time, the dimensions used to assess, and the factors that influence it. After that, the researchers identified important themes related to school readiness and assessment. The results of the FGD were then analyzed using the qualitative analysis model of Miles, Huberman, \& Saldaña (2014). Stages of analysis in this research included data collection, data display, data condensation, and conclusion drawing. 


\section{Ethical considerations}

To ensure the data obtained in this research is credible, all participants are coded. The purpose of the research was presented to the participants. The researchers assured all participants that the results of the research did not affect anything for them.

\section{RESULTS}

The results of the research are presented in the form of textual narratives. Researchers used qualitative data analysis software (Atlas.ti). The initial focus is on the frequency of words that appear in the data that provides the analysis of the strongest points when participants talk about their experiences. These important points can be interpreted from the representation of words that appear such as child, year (age), entry, elementary school, RA (Kindergarten under the minister of religion), kindergarten, readiness, learning, and assessment; shows how the assessment of readiness to enter primary school has played an important role in the experience of early childhood educators.

\section{Theme 1: School readiness assessors}

In general, school readiness assessments at formal early childhood education institutions in Indonesia are conducted by teachers, although explicitly they are not referred to as school readiness assessments. The assessment conducted by the teacher is an assessment of the child's developmental achievements according to his age development tasks. Psychologists carry out more professional assessors of school readiness. Recommendations for school readiness are made after the psychologist has tested the child's psychological readiness. Educators are not involved in the assessment conducted, this is reflected in the following interview passages during the FGD: conducted, this is reflected in the following interview passages during the FGD:

some are involved or not ... if the price is rather expensive, the teacher is not ... if the price is rather low, usually involved ... (some participants laugh) ... depends on the psychologist. (8:33).

... so, the teacher cannot judge what is written, scribbled by the child. However, psychologists who understand better. So even the teacher doesn't know ... this means the child is according to what the child is drawing. There is a privacy that is then passed on to parents. (8:35).

\section{Theme 2: Dimensions of school readiness}

The dimension of school readiness is interpreted as the achievement of children's development that is generally linear with chronological age growth. Therefore, based on the experience of early childhood educators, an assessment of school readiness can be indicated by the child's age or the level of achievement of child development. The standard of child development achievement that includes six aspects, (1) moral and religious, (2) physical motor, (3) cognitive, (4) language, (5) social-emotional, and (6) art. These aspects are is used as a reference for the level of children's readiness to learn formally in elementary school. Educators in designing education for early childhood also use these standards. This is reflected in the following interview excerpt:

Moral and religious, physical motor, cognitive, language, social-emotional, art. If all 6 developments are developing well, the child is ready to enter the next level of education. As for in principle the process of child development is different, but the 6th development will continue to increase with age. (4:1).

Maturity is the dominant factor in children's school readiness. The following description of the interview passage can be used as a representation of educators interpreting age as a dominant factor in children's school readiness:

... in my opinion, I agree with a minimum of six years, for example, less than six years.

That is indeed in terms of age, maturity, independence, ... it's rather lacking. Like that. In my opinion, it is agreed that even six years. a minimum of six years or up. From its 
independence and maturity, it is rather lacking, so. After I observe it from the graduates. You know, before last year, those under six years were not allowed to graduate. like that, but from the government, it can't be from the Ministry of Religion, but from the Institution, we can't yet. Because, ever graduated less than the age of six years, 5.8 may be that, at least 5.8 I graduated his child looked, lacked independence, lack of maturity, given the responsibility was somewhat lacking enthusiasm, something like that, anyway I was determined to know yesterday, six thanks, the guardian also wants. (8: 65).

The ability to read, write and count is not a developmental achievement that can indicate a child's readiness to take lessons in elementary school. This ability cannot be used as a predictor for future learning achievement in school. The following interview passages can represent this:

For calistung [writing, reading, and counting ability], it is not a priority to prepare for elementary school, although in kindergarten there are activities or learning about letters and numbers. It is intended to introduce symbols to prepare for a reading, writing, and arithmetic with the method of learning while playing. (6: 21).

the child is not sure, in kindergarten, in RA [kindergarten under the minister of religion], he is clever, he can read, can write, in elementary school, he is not necessarily smart. (8: 2).

\section{Theme 3: School readiness assessment}

Early childhood educators carry out school readiness assessment based on child development achievements. On the side of the form of assessment that is commonly used are performance appraisal and observation. Educators use daily assessment in assessing children's developmental achievements. In some cases, "summative" assessments are used but only as a form of formality due to demands from parents of students. The assessment is not used as a judgment of the child's developmental achievements. The commonly used instrument is the assessment rubric. Here are some excerpts from the interview representation about the school readiness assessment:

Related to assessment for early childhood. That indeed we get the assessment with the child's daily processes and for example in a one-week cognitive assessment of one child. The first ... has not yet appeared, the second began to emerge, the third developed according to expectations, and the next is developing very well. Then the best value is taken to be uploaded to report cards, like that. In our experience. (8: 83).

if we take the evaluation period, even afraid when the evaluation, when the child is not in the mood, not done, the value is not there. We take the daily one, yes, the daily value entered into the report book. (8: 50).

Educators use an assessment rubric instrument that is independently developed according to Early Childhood Development Achievement Standards (STPPA). Reference levels of achievement are based on the experience of assessing educators. The expectation of a standard assessment rubric that can be used as a reference, objective, easy to use, and valid is illustrated in the following interview passage:

in my RA, it is indeed subjective from each teacher or homeroom teacher. In my opinion, it is necessary, because so that the teacher also knows, between one teacher and another the assessment of ... has not yet developed, started to develop, or developed according to expectations, and develops very well it also wants standards that are true as to what (8: 51).

In my opinion, it is very necessary, because the assessment is not just us who know, such as there are assessors or supervisors, they want to see. How come you usually judge BSB [Very Well Developed]- very well developed] from where? Where is the BSB value from? Here is the reference, there is a rubric, so we don't make mistakes, we think we are subjective. How do you do it from here? Where do we stutter 
sometimes from? from this mom, from where? what do you mean? Like that, in my opinion, it is necessary to equate everything. So, it is not subjective, between one institution and the other institutions are all the same (8: 86).

and

... if the standard is indeed good, it would be better if all the practitioners from the PAUD themselves indeed, deepen about PAUD, could be implemented to make the rubric itself. But for the achievement of the child, there is already a standard in the STPPA. For example, in the child's kinesthetic for assessment that has not yet appeared, what is it like? We even have games jumping from number one to number 10 , in one box. That is if the first one has not yet appeared, that child has not moved, said nothing, it has not yet appeared. Then the child can step once into the box or twice the child starts to appear, and for those who develop according to expectations, the child can all 1, 2, 3, 4, 5, 6 to 10. It starts to appear. And that developed very well that he was fast, faster than the specified time. Like that. So, it develops very well. So, there is a difference between the abilities of children not yet appearing, starting to appear, developing according to expectations, and developing very well. (8: 89).

\section{Theme 4: School readiness development strategies}

Six aspects of STPPA were developed in the design of learning for early childhood in the age frame of play. Media that are interesting and fun for children are also of particular concern in the design of children's development stimulation. Emotional social habits such as independence, responsibility become a pressure point in preparing children's development achievements according to their age. Besides, motor and cognitive habituation is the focus of the development of STPPA. Like the formative rubric, assessment has an important role as a daily instrument in assessing the child's developmental achievements over time.

Developing religious and moral values, developing emotional social abilities, developing physical motor skills, developing language skills, developing cognitive abilities, developing artistic abilities (2: 6).

Preparing children to be independent, confident, and able to adapt and socialize also in terms of language and mental, and physical. (5: 7).

and

Train the child's fine motor skills to make the muscles more flexible by squeezing paper, plasticine, etc. Imitate various forms, move fingers by cutting, sticking, and others. So that children can use stationery correctly. Cultivate self-confidence by always giving praise and a good response to children. (6:16).

\section{DISCUSSION and CONCLUSIONS}

Readiness concerns not only the children's academic skills and knowledge but also the capacity of families, schools, and communities to prepare these children to succeed in school (Brown, 2010). Brown A. L's (2012) research results seem to indicate that the curriculum used by the Home Instruction for Parents of Preschool Youngsters program, which focuses on supporting parents as their child's first teacher, helps reduce the potential negative impact on becoming a child of a teenage mother. Manipulative skills and balance provide evidence that for preschoolers whose nerve representations of the extremities are not yet precise and stable, skilled gross motor manipulation is an important developmental achievement (Iivonena et al., 2011). Children who participate regularly in the motor skills intervention program show significantly better gross motor skills and improve cognitive function (Draper et al., 2012). Fundamental movement skills (fundamental motor skills) including locomotor substance and object control are most successfully obtained during the early years of school (Mukherjee et al., 2017) Age is the best predictor for all skills involved in school readiness (Guarnera et al., 2017). 
The school readiness level/assessment tool/questionnaire completed by the teacher, during the first month of kindergarten, was significantly associated with students' reading fluency and various indicators of their social-emotional well-being during Class 5 (Quirk et al., 2017). The five-factor structure which includes self and social development, language and literacy development, language development, cognitive development, mathematical development, physical development, and health which are proposed best fits the data, with greater embodiment and statistical validity (Abdulfattah \& Putranta, 2020; Nguyen et al., 2019). While Roberts-Holmes (2019) found four dimensions in early childhood school readiness, namely Phonics, Literacy, Mathematics, and Reading.

Setiawati et al. (2017) show the dimensions of children's learning readiness to enter primary school in the Indonesian context as (1) cognitive and language aspects, which consist of recognizing letters, reading, recognizing numbers, counting, building public spaces, understanding instructions, and information, speak fluently, tell stories, and solve problems; (2) social emotional aspects, which consist of teamwork, socialization with peers, class adaptation, independence, understanding the rules, discipline, helping others; (3) other aspects, consisting of concentration, parental attention, and age; (4) aspects of fine motor skills, which consist of writing, cutting and sticking, holding stationery, and drawing lines; (5) gross motor skills consisting of mimicking (running, jumping, and standing on one leg) or dancing; (6) art, which consists of memorizing poetry, drawing, and creativity; and (7) religion and other moral aspects, which consist of religious activities such as prayer, reading the Koran, and charity.

Assessment using testing for pre-school children has been started since the 1960s (Kelly \& Surbeck, 2003). Since then, the assessment of this model has been criticized for a variety of limitations, including the use of inappropriate instruments (Meisels, 1998) and the lack of clarity like psychometrics to assess children under 4 years of age (Bracken, 1987). However, when used appropriately, this assessment will be useful in identifying children's readiness, the need for early intervention and providing information to educators in understanding children's readiness and school adjustments (Ackesjö, 2015; Amerijckx \& Humblet, 2015; Sha \& Li, 2019; Wellisch, 2019). There are two methods of assessment that are commonly used in pre-school assessments, namely assessment with standard instruments as a reference and authentic assessment. Teachers collect performance-based observational measurements from several sources, including notes and samples of children's performance using checklists or scales to obtain information on expected levels of developmental achievement (Meisels, 1998; Riley-Ayers, 2014). Performance-based assessment is intended to be used repeatedly, so educators have a good and valid understanding of child development (Riley-Ayers, 2014).

Ohle and Harve (2017) concluded that educators view the readiness of multidimensional schools. They assume that the more important is the dimension of school readiness; children come to school to be themselves. STPPA as a basis for achieving child development, which is an aspect of assessment, is in line with the chronological age of students. This has an important role as the conceptual framework of children's readiness for schools, which is one of the 3 components of UNICEF's readiness (2012). Roberts et al., (2011) found that children who enter school too early tend to be vulnerable in more than one school readiness domain. Cognitive, socialemotional, motoric, and developmental development strategies in STPPA are important to facilitate children to obtain maturity and independence with the help of adequate systems and infrastructure (Amerijckx \& Humblet, 2015). Daily assessment strategies are appropriate for early childhood educators to use as previous findings which find it more appropriate to use informal assessment (Brown \& Rolfe 2005). Wortham (2008) suggested that limited language skills would be difficult for children to demonstrate knowledge and understanding using structured tasks.

The concept of school readiness has been widely recognized by early childhood educators and affects the process of early childhood learning. Educators' perceptions of the dimensions of school readiness are based on the achievements of children's development, which include moral and religious values, physical-motor, cognitive, language, social-emotional, and art. The assessment of the child's developmental achievements is carried out formative with most using performance assessments. The plural assessment rubric is used as an observation instrument for 
the child's performance. This research has the limitation of only exploring assessment from the perspective of early childhood educators. Exploring from the perspective of educators in primary schools may provide a more comprehensive picture of school readiness and the things that influence it, especially in the early elementary school age. Another limitation is the readiness aspect only from the child's side. Using the concept of framework readiness from UNICEF (2012), by completing studies on the perspective of school readiness to accept children's and parents' readiness will certainly make their perspectives more complete.

\section{REFERENCES}

Abdulfattah, A., \& Putranta, H. (2020). The development of mobile learning-assisted local culture-based subject-specific pedagogy in realizing the learning outcomes of physics subjects. In International Conference on Educational Research and Innovation (ICERI 2019) (pp. 71-78). Atlantis Press.

Ackesjö, H. (2014). Children's transitions to school in a changing educational landscape: borders, identities, and (dis-) continuities. International Journal of Transitions in Childhood 7(2), 3-15.

Amerijckx, G., \& Humblet, P. C. (2015). The transition to preschool: a problem or an opportunity for children? A sociological perspective in the context of a 'split-system'. European Early Childhood Education Research Journal 23(1), 99-111.

Ansari, A., Purtell, K., \& Gershoff, E. (2016). Classroom age composition and the school readiness of 3-and 4-year-olds in the Head Start program. Psychological Science 27(1), 53-63.

Arifin, S., Retnawati, H., Mailool, J., \& Putranta, H. (2020). The factors that influence of reading ability the Hijaiyah alphabet on pre-school children. Journal for the Education of Gifted Young Scientists 8(2), 667-680.

Bassok, D., \& Latham, S. (2017). Kids today: The rise in children's academic skills at kindergarten entry. Educational Researcher, 46(1), 7-20.

Bennett, J. (2013). A response from the co-author of 'a strong and equal partnership'. In Moss, P. In Early Childhood and Compulsory Education (pp. 60-79). London: Routledge.

Blair, C., \& Raver, C. C. (2015). School readiness and self-regulation: A developmental psychobiological approach. Annual Review of Psychology, 66(4) 711-731.

Booth, A., O'Farrelly, C., Hennessy, E., \& Doyle, O. (2019). 'Be good, know the rules': Children's perspectives on starting school and self-regulation. Childhood 26(4), 509-524.

Bracken, B. A. (1987). Limitations of preschool instruments and standards for minimal levels of technical adequacy. Journal of Psychoeducational Assessment 5(4), 313-326.

Britto, P. R. (2012). School readiness. New York: United Nations Children's Fund.

Brooks, E., \& Murray, J. (2018). Ready, steady, learn: school readiness and children's voices in English early childhood settings. Education 3-13 46(2), 143-156.

Broström, S. (2005). Transition problems and play as transitory activity. Australasian Journal of Early Childhood 30(3), 17-25.

Brown, J., \& Rolfe, S. A. (2005). Use of child development assessment in early childhood education: Early childhood practitioner and student attitudes toward formal and informal testing. Early Child Development and Care 175(3), 193-202.

Bustamante, A. S., \& Hindman, A. H. (2019). Classroom quality and academic school readiness outcomes in Head Start: The indirect effect of approaches to learning. Early Education and Development 30(1), 19-35.

Creswell, J. W. (2013). Research design: qualitative, quantitative, and mixed methods approaches. California, USA: Sage publications, inc.

DfE. (2016). Department for Education 'Evidence check' memorandum school starting age. Retrieved 12 October 2019 from https://www.parliament.uk/documents/commonscommittees/Education/evidence-check-forum/School-starting-age.pdf.

Djoehaeni, H. (2005). Pengembangan potensi anak usia dini melalui penerapan kelas yang berpusat pada anak [Early childhood potential development through the implementation of child-centered classrooms]. Jurnal Pendidikan Anak Usia Dini 1(7), 38-47.

Guarnera, M., Faraci, P., Commodari, E., \& Buccheri, S. L. (2017). Mental imagery and school readiness. Psychological Reports 120(6), 1058-1077.

Halimah, N., \& Kawuryan, F. (2010). Kesiapan memasuki sekolah dasar pada anak yang mengikuti pendidikan TK dengan yang tidak mengikuti pendidikan TK di Kabupaten Kudus [ Readiness to enter elementary school for children who attend kindergarten education and those who do not attend kindergarten education in Kudus district]. Jurnal Psikologi UMK: PITUTUR 1(1), 1-8. 
Hamerslag, R., Oostdam, R., \& Tavecchio, L. (2018). Inside school readiness: the role of socioemotional and behavioral factors in relation to school, teachers, peers, and academic outcome in kindergarten and first grade. European Early Childhood Education Research Journal 26(1), 80-96.

Harris, F., Smith, M., Laurens, K. R., Green, M. J., Tzoumakis, S., Kariuki, M., \& Carr, V. J. (2018). Validation of a two-factor model of the Best Start Kindergarten Assessment of literacy and numeracy. Australian Journal of Education 62(1), 36-48.

Hellblom-Thibblin, T., Sandberg, G., \& Garpelin, A. (2017). Obstacles and Challenges in Gaining Knowledge for Constructing Inclusive Educational Practice: Teachers' Perspectives. In Pedagogies of Educational Transitions (pp. 43-58). Springer, Cham.

Roberts-Holmes, G. (2019). School readiness, governance, and early years ability grouping. Contemporary Issues in Early Childhood 2(5), 146-154.

Hughes, C., White, N., Foley, S., \& Devine, R. T. (2018). Family support and gains in school readiness: A longitudinal study. British Journal of Educational Psychology 88(2), 284-299.

Kelly, M. F., \& Surbeck, E. (2003). History of preschool assessment. In B. A. Bracken, \& R. J. (Eds.), Psychoeducational assessment of preschool children, pp. 3-28. Mahwah, NJ: Lawrence Erlbaum Associates, Inc.

Kull, M. A., \& Coley, R. L. (2015). Early physical health conditions and school readiness skills in a prospective birth cohort of US children. Social Science \& Medicine 142(5), 145-153.

Li, J. B., \& Lau, E. Y. H. (2019). Teacher-student conflict and preschoolers' adjustment in the transition to primary school: The role of child self-regulation and parents' positive relations with others. Early Education and Development 30(3), 423-437.

Limlingan, M. C., McWayne, C. M., Sanders, E. A., \& López, M. L. (2020). Classroom language contexts as predictors of Latinx preschool dual language learners' school readiness. American Educational Research Journal 57(1), 339-370.

Majzub, R. M., \& Rashid, A. A. (2012). School readiness among preschool children. Procedia-Social and Behavioral Sciences 46(9), 3524-3529.

Maxwell, K. L., \& Clifford, R. M. (2004). School readiness assessment. Young Children 59(1), 42-46.

Meisels, S. J. (1998). Assessing readiness. Ann Arbor, MI: CIERA Report \# 3-002.

Merleau-Ponty, M., \& Bannan, J. F. (1956). What is phenomenology? Crosscurrents, 6(1), 59-70.

Miles, M. B., Huberman, A. M., \& Saldaña, J. (2014). Qualitative data analysis. A Methods Sourcebook. California, USA: SAGE Publications.

Miller-Bains, K. L., Russo, J. M., Williford, A. P., DeCoster, J., \& Cottone, E. A. (2017). Examining the validity of a multidimensional performance-based assessment at kindergarten entry. AERA Open 3(2), 2332858417706969.

Moss, P. (2013). Early childhood and compulsory education: Reconceptualizing the relationship. London: Routledge.

NCES (2016). Digest of Education Statistics: 2015. Retrieved 29 Oktober, 2019 https://nces.ed.gov/programs/digest/d15/ch_1.asp.

Nguyen, T., Reich, S. M., Jenkins, J. M., \& Abedi, J. (2020). Psychometric validation and reorganization of the desired results developmental profile. Journal of Psychoeducational Assessment 38(3), 369-388.

Niklas, F., Cohrssen, C., Vidmar, M., Segerer, R., Schmiedeler, S., Galpin, R., \& Tayler, C. (2018). Early childhood professionals' perceptions of children's school readiness characteristics in six countries. International Journal of Educational Research 90(8), 144-159.

Ohle, K. A., \& Harvey, H. A. (2019). Educators' perceptions of school readiness within the context of a kindergarten entry assessment in Alaska. Early Child Development and Care 189(11), 1859-1873.

Putranta, H., \& Wilujeng, I. (2019). Physics learning by PhET simulation-assisted using problem based learning (PBL) model to improve students' critical thinking skills in work and energy chapters in MAN 3 Sleman. Asia-Pacific Forum on Science Learning and Teaching 20(1), 1-44).

Quirk, M., Dowdy, E., Goldstein, A., \& Carnazzo, K. (2017). School readiness as a longitudinal predictor of social-emotional and reading performance across the elementary grades. Assessment for Effective Intervention 42(4), 248-253.

Raikes, A., Koziol, N., Janus, M., Platas, L., Weatherholt, T., Smeby, A., \& Sayre, R. (2019). Examination of school readiness constructs in Tanzania: Psychometric evaluation of the MELQO scales. Journal of Applied Developmental Psychology 62(4), 122-134.

Riley-Ayers, S. (2014). Formative assessment: Guidance for early childhood policymakers. New Brunswick, NJ: Center on Enhancing Early Learning Outcomes.

Roberts, G., Lim, J., Doyle, L. W., \& Anderson, P. J. (2011). High rates of school readiness difficulties at 5 years of age in very preterm infants compared with term controls. Journal of Developmental \& Behavioral Pediatrics 32(2), 117-124. 
Russo, J. M., Williford, A. P., Markowitz, A. J., Vitiello, V. E., \& Bassok, D. (2019). Examining the validity of a widely-used school readiness assessment: Implications for teachers and early childhood programs. Early Childhood Research Quarterly 48(6), 14-25.

Setiawati, F. A., Izzaty, R. E., \& Triyanto, A. (2017). Exploring the construct of school readiness based on child development for kindergarten children. REiD (Research and Evaluation in Education) 3(1), 42-49.

Xie, S., \& Li, H. (2019). Development and validation of the Chinese preschool readiness scale. Early Education and Development 30(4), 522-539.

Tortella, P., Haga, M., Loras, H., Sigmundsson, H., \& Fumagalli, G. (2016). Motor skill development in Italian pre-school children induced by structured activities in a specific playground. PLoS One 11(7), e0160244.

UNICEF. (2012). School readiness a conceptual framework. New York: United Nations Children's Fund.

Van Laere, K., \& Vandenbroeck, M. (2017). Early learning in preschool: meaningful and inclusive for all? Exploring perspectives of migrant parents and staff. European Early Childhood Education Research Journal 25(2), 243-257.

Weegar, K., Guérin-Marion, C., Fréchette, S., \& Romano, E. (2018). Child physical punishment, parenting, and school readiness. Infant and Child Development 27(1), e2050.

Wellisch, M. (2019). Ceilinged out: Gifted preschoolers in early childhood services. Journal of Advanced Academics 30(3), 326-354.

Wilder, J., \& Lillvist, A. (2017). Hope, despair, and everything in between-parental expectations of educational transition for young children with intellectual disability. In Families and Transition to School (pp. 51-66). Springer, Cham.

Willoughby, M. T., Magnus, B., Vernon-Feagans, L., Blair, C. B., \& Family Life Project Investigators. (2017). Developmental delays in executive function from 3 to 5 years of age predict kindergarten academic readiness. Journal of Learning Disabilities 50(4), 359-372.

Wolf, S., Halpin, P., Yoshikawa, H., Dowd, A. J., Pisani, L., \& Borisova, I. (2017). Measuring school rea diness globally: Assessing the construct validity and measurement invariance of the international development and early learning assessment (IDELA) in Ethiopia. Early Childhood Research Quarterly 41(7), 21-36.

Wood, E. (2019). Unbalanced and unbalancing acts in the Early Years Foundation Stage: a critical discourse analysis of policy-led evidence on teaching and play from the office for standards in education in England (Ofsted). Education 3-13 47(7), 784-795.

Wortham. S. C. (2008). Assessment in early childhood education. Columbus, OH: Pearson Prentice Hall 